G U I L T KNOWLEDGE, G UILTY PLEASURE 
Also by William Logan

POETRY

Sad-faced Men (1982)

Difficulty (1985)

Sullen Weedy Lakes (1988)

Vain Empires (1998)

Night Battle (1999)

Macbeth in Venice (2003)

The Whispering Gallery (2005)

Strange Flesh (2008)

Deception Island: Selected Early Poems (2011)

Madame X (2012)

CRITICIS M

All the Rage (1998)

Reputations of the Tongue (1999)

Desperate Measures (2002)

The Undiscovered Country (2005)

Our Savage Art (2009)

\section{EDITIONS}

Randall Jarrell, Poetry and the Age, expanded edition (2001)

John Townsend Trowbridge, Guy Vernon (2012) 


\title{
Guilty Knowledge, Guilty Pleasure
}

\author{
THE DIRTY ART OF POETRY
}

W I L L I A M L O G A N 


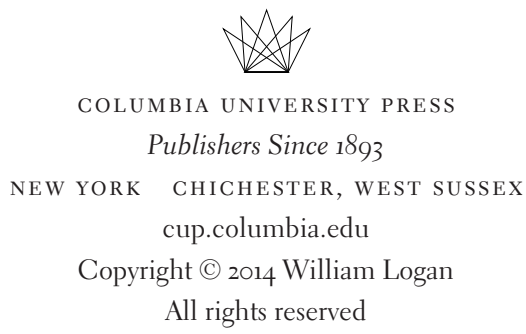

Library of Congress Cataloging-in-Publication Data

Logan, William, 1950-

Guilty knowledge, guilty pleasure : the dirty art of poetry / William Logan.

pages $\mathrm{cm}$

Includes bibliographical references and index.

ISBN 978-o-231-16686-7 (cloth : alk. paper) — ISBN 978-o-231-53723-o (e-book)

1. American poetry - 2oth century - History and criticism - Theory, etc.

2. Criticism-United States-History - 2oth century. 3. American poetry2oth century-History and criticism. 4. Poetry-Authorship. 5. Poetics. I. Title.

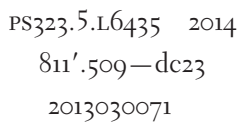

(2)

Columbia University Press books are printed on permanent and durable acid-free paper. This book is printed on paper with recycled content.

Printed in the United States of America

$$
\text { c } 10987654321
$$

JACKET IMAGE: COLLAGE BY DEBORA GREGER 
For Dorothy Drew Damon and Young Buffalo 

He is charged with the guilty knowledge of this concealment. He must show, not say, how he came by this knowledge. If a man be found with stolen goods, he must prove how he came by them.

-Daniel Webster, Speeches and Forensic Arguments, vol. 1 (1835)

Thus, in the midst of riot, imagined spectres have been known to haunt the man of guilty pleasure. He sees hands coming forth to write on the wall against him. The very portraits of his ancestors, which hang in his hall, appear to him to look with frowning aspect.

-Hugh Blair, "On a Life of Dissipation and Pleasure,"

Sermons, vol. 2 (1822)

The fourth witness as to the guilty knowledge was the coachman, for though the press removed was not such a one as would print the paper, it at least showed an anxiety to get rid of a suspicious article.

-The Asiatic Journal and Monthly Register, September 1831

If he is dwelling with delight upon a stratagem of successful fraud, a night of licentious riot, or an intrigue of guilty pleasure, let him summon off his imagination as from an unlawful pursuit.

-Samuel Johnson, The Rambler, no. 8, April 14, 1750 
